UDC $332.2: 330.14: 338.43$

\title{
LAND CAPITAL IN AGRICULTURE: PECULIARITIES OF ASSESSMENT AND FORMATION
}

Dorosh Y., Doctor of Economics Sciences, docent,

Land Management Institute of the National Academy of Agrarian Sciences of

$$
\begin{gathered}
\text { Ukraine } \\
\text { e-mail: dorosholgas@ukr.net }
\end{gathered}
$$

Shkuratov O., Doctor of Economics Sciences, professor,

Land Management Institute of the National Academy of Agrarian Sciences of

Ukraine

e-mail:shkuratov@nas.gov.ua

Tarnopolskyi A.

Land Management Institute of the National Academy of Agrarian Sciences of Ukraine

e-mail:andrey0037@gmail.com

\section{Abstract.}

The article identifies that land resources are not only the basis for the allocation of productive forces and the main means of production in agriculture, but also serve as an effective element of investment capital of agricultural enterprises - land capital. It is determined that in the existing institutional conditions, land resources do not create capital in agricultural production, which requires justification of mechanisms for involving them in economic circulation in order to provide investment support to the agricultural sector of the economy. This increases the importance of the development of theoretical and methodological foundations for the assessment and formation of land capital in Ukrainian agriculture.

It is established that one of the key factors for the capitalization of agricultural lands is their objective assessment, which corresponds to the current economic conditions and reveals them as a source of capitalized income. Based on 
studies of the relationship between rental payments and land valuation, a disparity of these indicators has been identified in the majority of regions in Ukraine. As a result, the application of normative monetary valuation for determination of the value of land capital has been proven biased.

It is determined that one of the ways of estimation and formation of land capital in agriculture, under the conditions of institutionally restricted regime of the law of supply and demand, is the capitalization of leased land. In this case, the value of land capital can be calculated as the product of the average annual rent for the land and the period of its capitalization. A promising area of research in the context of the analysis is to substantiate the process of transferring agricultural land to the balance sheet of the enterprise at the cost of capitalized rental payments.

Keywords: land capital, agriculture, capitalization, investments, normative monetary valuation, rent.

Formulation of the problem. In Ukrainian economy, the land resources play a leading role as they are the main basis for agricultural production. Since land is an important productive force without which the agricultural production process is unthinkable, and it is the main and indispensable means of production, the need for rational and efficient use of land is dictated, above all, by its distinguishing features as a natural resource from other means of production. Indeed, agricultural land, characterized by a number of natural properties, including fertility, which, even without significant capital investment, is endowed with the ability to generate value in the process of biological transformation. In such circumstances, land resources are not only the basis for the allocation of productive forces and the main means of production in agriculture, but also serve as an element of capital at the expense of their investment properties [15]. Accordingly, in such conditions, the issues of increasing the level of capitalization of land resources and the formation of land capital in agriculture, with its further involvement in the economic circulation in order to increase the investment 
attractiveness of the agricultural sector of the economy, become relevant. However, further reform of land relations in the agricultural sector of the economy increases the need to study issues related to the valuation of land capital.

Analysis of recent research and publications. Important contribution to the development of theoretical and practical foundations of capitalization of land resources at the national level was made by well-known domestic scientists, in particular I.Bystryakov, M.Geenko, O.Lazareva, Sh.Chwesik and others. In particular, the works of A.Tretyak substantiate the theoretical and methodological foundations of the formation of land capital and recommendations for the evaluation of agricultural land $[12 ; 13]$. However, it should be noted that the landrelated valuation process has caused some difficulties in the land-valuation field to date. This is largely due to the underdevelopment of the main segment of the agricultural land market, namely its purchase and sale.

Research of scientists of the Institute of Economics of Nature Management and Sustainable Development of the National Academy of Sciences of Ukraine [5, p. 38] indicate that the main purpose of the process of capitalization of land resources is, in particular, to increase the intensity of land use while maintaining and restoring the potential productivity of soils, and the development of rural areas. At the same time, the capitalization of land itself, in their understanding, is a process of gradual increase in the value of land capital as a result of the action of objective regularities of spatial development and purposeful influence of the system of measures of economic, planning and administrative-organizational content on its growth [5].

O.Lazareva considers land capital as [6] "a set of benefits and a special quality, often inherent in the organic nature (and completely inorganic), by which organic life is maintained in a favorable external environment". At the same time, the content of the distribution of land wealth is a function of establishing the shares or proportions according to which the goods produced in the land are allocated to the subjects of land use [6]. S.Ibatullin notes that the capitalization of land resources is determined by such factors as the ratio of supply and demand of land, 
mechanisms of state and market regulation of land relations and their infrastructure, parameters of the functioning of the economic system [4].

However, despite the high level of results obtained by the mentioned authors, it should be noted that they remain rather controversial, and therefore require a theoretical and practical justification for the formation and assessment of land capital in terms of reform and limited agricultural land market.

Nowadays, due to the introduction of intensive production technologies in the agricultural sphere, the condition of the lands used for agriculture is deteriorating. The soil cover degrades, loses its resistance to destruction, decreases its ability to restore properties and reproduce fertility. In order to solve these problems, the comprehensive analysis of the state of the land potential attains great importance, as well as the development of ways to improve the results of its use, which will allow the reproduction of land resources. The solution to this problem is possible by providing land resources in agriculture with a form of capital in order to reflect their real market value.

The purpose of the article is to substantiate theoretical and methodological approaches and scientific and practical recommendations on the assessment and formation of land capital in the agriculture of Ukraine.

Materials and methods of the research. The information base of the research is the materials of the State Service of Ukraine for Geodesy, Cartography and Cadastre and the State Statistics Service of Ukraine, in particular regarding the indicators of normative monetary valuation and rent payments for land shares. Official data of the National Bank of Ukraine was used to determine the NBU discount rate. The theoretical and methodological basis of the study is the assumption of the mutual determination of such economic processes as the lease of agricultural land and its capitalization. On this basis, the methods and approaches of classical economic theory, institutional theory, land rent theory, value theory, consumer behavior in relation to the land market circulation, including systematic approach, methods of analysis and synthesis, calculation, constructive and experimental, were applied. An economic and statistical methods were used to 
process the statistics in the analysis of the ratio of the average annual rental payments to land plots to the value of the normative monetary value of arable and fallow lands.

Presenting main material. Land capital, like any other capital, is first and foremost the value of the means of production (land resources) used to generate additional value by engaging it in economic activity. Therefore, the acquisition of land features of capital, which can generate additional income, is likely only if they are attracted to economic circulation. In other words, land resources become land capital when the primary purpose and result of their use is to obtain value added. Given this, agricultural lands have considerable potential for investment in the domestic agricultural sector of the economy. A key factor in the capitalization of agricultural land, however, can be considered to be an estimate that meets current economic conditions and discloses them as a source of capitalized income.

The main task of valuation of agricultural land for determining the value of land capital involves, first of all, the determination of the part of the profit that they account for (as the main means of production). In the absence of a full-fledged agricultural land market, such valuation is possible as a result of their normative monetary valuation or sale of leasehold rights.

Calculation of the normative monetary valuation of agricultural lands in accordance with the Methodology of the normative monetary valuation of agricultural land and settlements [10] (the last estimation according to this method made as of 01.01.2017) is based on the rental income that is created in the production of crops and is determined by land economic valuation data for 1988 . The normative monetary valuation of agricultural land was defined as the product of the annual rental income and the period of its capitalization, which was adopted at the level of 33 years. That is, the rate of capitalization of agricultural land was about $3 \%$. Due to the fact that the mentioned methodology did not take into account changes in the economy and system of agricultural land use in the conditions of land reform, in 2016, a new Methodology for the normative monetary valuation of agricultural land was adopted [9], according to which the 
evaluation of agricultural land is determined in accordance with the standard of capitalized rental income on agricultural lands of natural and agricultural regions of the Autonomous Republic of Crimea, regions, cities of Kyiv and Sevastopol, according to the appendix and indicators of soil boning by drawing up scales of normative monetary assessment of agricultural groups of soils of natural and agricultural areas (for agricultural land). However, this methodology did not specify either the annual rental income by which the rate of capitalized rental income was calculated nor the terms of the capitalization itself.

Based on the assumptions that the rates of capitalized rental income ratios in the above-mentioned methodology are calculated in accordance with the scientific developments of A.Martin [7], the rental income according to the new methodology was calculated on the basis of statistics for the period 2008-2011. The amount of rental income was determined as the sum of its following components:

- part of the result of operating activities of agricultural enterprises, which they received above the level of profitability, is characteristic of non-profitable (non-agricultural) sectors of the economy of Ukraine as a whole;

- part of the expenses that are due for the payment of rent to the owners of land plots (land shares);

- part of the expenses related to the payment of rent for land of state and communal property of agricultural purpose;

- absolute rental income generated by state support for Ukraine's agriculture.

In the work of A.Martin [7], the rate of capitalization of rental income is also specified, which in his opinion, should be equated with the discount rate of the National Bank of Ukraine in the year of assessment, ie 7.75\% (as of 2012). On this basis, the capitalization of agricultural land was approximately 13 years in 2012 . However, taking into account the fact that the methodology was approved in 2016, it can be assumed that the discount rate of the National Bank of Ukraine as of 
January 1, 2016 was already 14\%. And this, in turn, says about the term of capitalization of rental income about 7 years.

In general, the normative monetary valuation of land plots is mainly used to determine the amount of land tax, losses of agricultural and forestry production, economic incentives for rational use and protection of land, etc. [3]. However, in the absence of a full agricultural land market, it is possible to apply the results of such an assessment to other purposes of the market circulation of land, including lease relations. Yes, according to Article 288 of the Tax Code of Ukraine the rent is set in the lease, but the annual payment cannot be less than the amount of land tax (that is, for most agricultural lands not less than $0.3 \%$ of their normative monetary valuation) and exceed $12 \%$ of the normative monetary valuation (except when the tenant is determined on a competitive basis) [8].

Indeed, in connection with the introduction of a moratorium on the sale of most agricultural land, leasing is by far the most common form of marketed land in agriculture today. The basis of the economic relationship between the tenant and the landlord is the lease payments, which reflect the relationship of ownership, use and disposal of land ownership. Therefore, the economically justified amount of rental rates is the main parameter that reflects the economic meaning of rental relations [1; 2]. Agricultural producers of Ukraine conduct their business mainly on leased lands, whose share in the total land use of the agricultural sector of the economy is more than $40 \%$ [2].

Therefore, we consider it expedient to analyze the mutual impact of such important elements of domestic land use as normative monetary valuation and lease of agricultural land. There are actually two different forms of agricultural land lease in Ukraine today: 1) competitive through auctioning of state and communal agricultural land leases; 2) on a contractual basis by signing a lease of land (plots) contract. Given that the vast majority of land in Ukraine is leased from land owners, and for the sake of objectivity (due to the peculiarities of statistics), it is the second form of lease relationship that is selected for analysis. Given that leased land accounts for about 95-97\% of agricultural land such as arable land, 
indicators of a normative monetary valuation of this type of land were selected for comparative analysis (Table 1). As we can see, according to the calculations of the normative monetary assessment of arable and fallow lands in Ukraine according to the new methodology, the arable land capitalization has decreased on the average in Ukraine by 3417.5 UAH / ha. The rent increased by UAH 520.0 / ha, which indicates some discrepancies in the land relations of the domestic agrarian sphere in terms of the theory of land rent.

Table 1

Indicators of normative monetary valuation of arable and fallow lands and rent for land shares (plots) by regions of Ukraine, information as of 01.01. corresponding year (UAH / ha)

\begin{tabular}{|c|c|c|c|c|c|c|c|c|}
\hline \multirow[b]{2}{*}{ Region (oblast') } & \multicolumn{4}{|c|}{$\begin{array}{c}\text { Normative monetary assessment of arable } \\
\text { and fallow lands }\end{array}$} & \multicolumn{4}{|c|}{$\begin{array}{c}\text { Average annual rental fee for } \\
\text { land plots }\end{array}$} \\
\hline & $2017 *$ & $2018 * *$ & $2019 * *$ & $\begin{array}{l}2019+,- \\
\text { до } 2017\end{array}$ & 2017 & 2018 & 2019 & $\begin{array}{c}2019 \\
+,- \text { до } \\
2017\end{array}$ \\
\hline Vinnytsia & 33073,4 & 27078,3 & 27078,3 & $-5995,1$ & 1090,9 & 1504,2 & 2165,9 & $+1075,0$ \\
\hline Volyn’ & 29940,4 & 21607,4 & 21607,4 & $-8333,0$ & 989,5 & 1067,2 & 1166,5 & $+177,0$ \\
\hline Dnipropetrovsk & 32526,0 & 27078,3 & 27078,3 & $-5447,7$ & 949,9 & 1012,9 & 1275,9 & $+326,0$ \\
\hline Donetsk & 34854,7 & 31167,7 & 31167,7 & $-3687,0$ & 790,5 & 878,7 & 945,6 & $+155,1$ \\
\hline Zhytomyr & 20581,0 & 21165,3 & 21165,3 & $+584,3$ & 1054,1 & 1266,3 & 1687,1 & $+633,0$ \\
\hline Zakarpattya & 26377,9 & 27520,4 & 27520,4 & $+1142,5$ & 596,0 & 718,9 & 930,6 & $+334,6$ \\
\hline Zaporizhzhya & 33838,4 & 25254,6 & 25254,6 & $-8583,8$ & 721,4 & 794,7 & 878,0 & $+156,6$ \\
\hline Ivano-Frankivsk & 28567,6 & 26194,1 & 26194,1 & $-2373,5$ & 919,1 & 1104,5 & 1365,1 & $+446,0$ \\
\hline Kyiv & 31970,2 & 26194,1 & 26194,1 & $-5776,1$ & 533,4 & 1538,7 & 1826,8 & $+1293,4$ \\
\hline Kirovohrad & 32096,5 & 32107,1 & 32107,1 & $+10,6$ & 1168,2 & 1409,1 & 1422,4 & $+254,2$ \\
\hline Lugansk & 26519,1 & 27078,3 & 27078,3 & $+559,2$ & 834,9 & 864,0 & 1010,9 & $+176,0$ \\
\hline Lviv & 26622,1 & 22049,5 & 22049,5 & $-4572,6$ & 1132,3 & 1472,4 & 1723,6 & $+591,3$ \\
\hline Mykolaiv & 26360,2 & 27078,3 & 27078,3 & $+718,1$ & 819,8 & 825,8 & 1075,8 & $+256,0$ \\
\hline Odessa & 28114,2 & 31167,7 & 31167,7 & $+3053,5$ & 877,1 & 975,0 & 1496,9 & $+619,8$ \\
\hline Poltava & 34252,5 & 30283,5 & 30283,5 & $-3969,0$ & 2243,2 & 2553,0 & 2970,1 & $+726,9$ \\
\hline Rivne & 31406,0 & 22049,5 & 22049,5 & $-9356,5$ & 1371,7 & 1496,4 & 1689,2 & $+317,5$ \\
\hline Sumy & 29426,7 & 26636,2 & 26636,2 & $-2790,5$ & 1307,7 & 2100,2 & 1920,5 & $+612,8$ \\
\hline Ternopil' & 30039,4 & 28901,9 & 28901,9 & $-1137,5$ & 672,3 & 1242,0 & 1465,0 & $+792,7$ \\
\hline Kharkiv & 32505,5 & 32549,2 & 32549,2 & $+43,7$ & 2215,5 & 2111,0 & 2494,7 & $+279,2$ \\
\hline Kherson & 34698,9 & 24370,5 & 24370,5 & $-10328,0$ & 762,8 & 842,3 & 926,9 & $+164,1$ \\
\hline Khmelnytsky & 34495,6 & 29841,4 & 29841,4 & $-4654,2$ & 1397,9 & 1602 & 2267,3 & $+869,4$ \\
\hline Cherkasy & 39810,8 & 33930,8 & 33930,8 & $-5880,0$ & 2215,5 & 2961,8 & 3524,7 & $+1309,2$ \\
\hline Chernivtsi & 33999,8 & 32991,3 & 32991,3 & $-1008,5$ & 1111,3 & 1323,4 & 1364,5 & $+253,2$ \\
\hline Chernihiv & 24423,2 & 23873,1 & 23873,1 & $-550,1$ & 1078,5 & 1191,7 & 1127,7 & $+49,2$ \\
\hline $\begin{array}{l}\text { Average in } \\
\text { Ukraine: }\end{array}$ & 30937,9 & 27520,4 & 27520,4 & -3417 & 1093,4 & 1369,0 & 1613,4 & $+\mathbf{5 2 0 , 0}$ \\
\hline
\end{tabular}


Note: * calculated in accordance with the Methodology for normative monetary valuation of agricultural lands and settlements (1995);

** calculated in accordance with the Methodology for normative monetary valuation of agricultural lands (2016).

Source: Analytical data of the State Geocadastre (excluding the Autonomous Republic of Crimea and temporarily occupied territories in Donetsk and Lugansk regions).

Analyzing the indicators of the ratio of rent for land plots and the normative monetary valuation of arable fallow lands, it is worth noting an increase of their values in 2019 compared to 2017 on average in Ukraine by $2.3 \%$ (Table 2).

Table 2

Indicators of the ratio of rent for land plots (shares) to the normative monetary assessment of arable and fallow lands by regions of Ukraine, information as of 01.01. corresponding year (\%)

\begin{tabular}{|l|c|c|c|c|}
\hline \multicolumn{1}{|c|}{ Region (oblast') } & $\mathbf{2 0 1 7}$ & $\mathbf{2 0 1 8}$ & $\mathbf{2 0 1 9}$ & $\begin{array}{c}\mathbf{2 0 1 9}+\mathbf{+ -} \text { до } \\
\mathbf{2 0 1 7}\end{array}$ \\
\hline Vinnytsia & 3,3 & 5,6 & 8,0 & $+4,7$ \\
\hline Volyn' & 3,3 & 4,9 & 5,4 & $+2,1$ \\
\hline Dnipropetrovsk & 2,9 & 3,7 & 4,7 & $+1,8$ \\
\hline Donetsk & 2,3 & 2,8 & 3,0 & $+0,8$ \\
\hline Zhytomyr & 5,1 & 6,0 & 8,0 & $+2,8$ \\
\hline Zakarpattya & 2,3 & 2,6 & 3,4 & $+1,1$ \\
\hline Zaporizhzhya & 2,1 & 3,1 & 3,5 & $+1,3$ \\
\hline Ivano-Frankivsk & 3,2 & 4,2 & 5,2 & $+2,0$ \\
\hline Kyiv & 1,7 & 5,9 & 7,0 & $+5,3$ \\
\hline Kirovohrad & 3,6 & 4,4 & 4,4 & $+0,8$ \\
\hline Lugansk & 3,1 & 3,2 & 3,7 & $+0,6$ \\
\hline Lviv & 4,3 & 6,7 & 7,8 & $+3,6$ \\
\hline Mykolaiv & 3,1 & 3,0 & 4,0 & $+0,9$ \\
\hline Odessa & 3,1 & 3,1 & 4,8 & $+1,7$ \\
\hline Poltava & 6,5 & 8,4 & 9,8 & $+3,3$ \\
\hline Rivne & 4,4 & 6,8 & 7,7 & $+3,3$ \\
\hline Sumy & 4,4 & 7,9 & 7,2 & $+2,8$ \\
\hline Ternopil' & 2,2 & 4,3 & 5,1 & $+2,8$ \\
\hline Kharkiv & 6,8 & 6,5 & 7,7 & $+0,8$ \\
\hline Kherson & 2,2 & 3,5 & 3,8 & $+1,6$ \\
\hline Khmelnytsky & 4,1 & 5,4 & 7,6 & $+3,5$ \\
\hline Cherkasy & 5,6 & 8,7 & 10,4 & $+4,8$ \\
\hline Chernivtsi & 3,3 & 4,0 & 4,1 & $+0,9$ \\
\hline Chernihiv & 4,4 & 5,0 & 4,7 & $+0,3$ \\
\hline Average in Ukraine: & $\mathbf{3 , 5}$ & $\mathbf{5 , 0}$ & $\mathbf{5 , 9}$ & $+\mathbf{2 , 3}$ \\
\hline
\end{tabular}


Source: calculated according to the analytical data of the State Geocadastre (excluding the Autonomous Republic of Crimea and the temporarily occupied territories in Donetsk and Luhansk regions).

For better perception and further analysis, we present the results of the percentage ratio of average annual rental payments for shares to the value of normative monetary assessment of arable fallow lands in the regions of Ukraine in graphical form (Fig. 1).

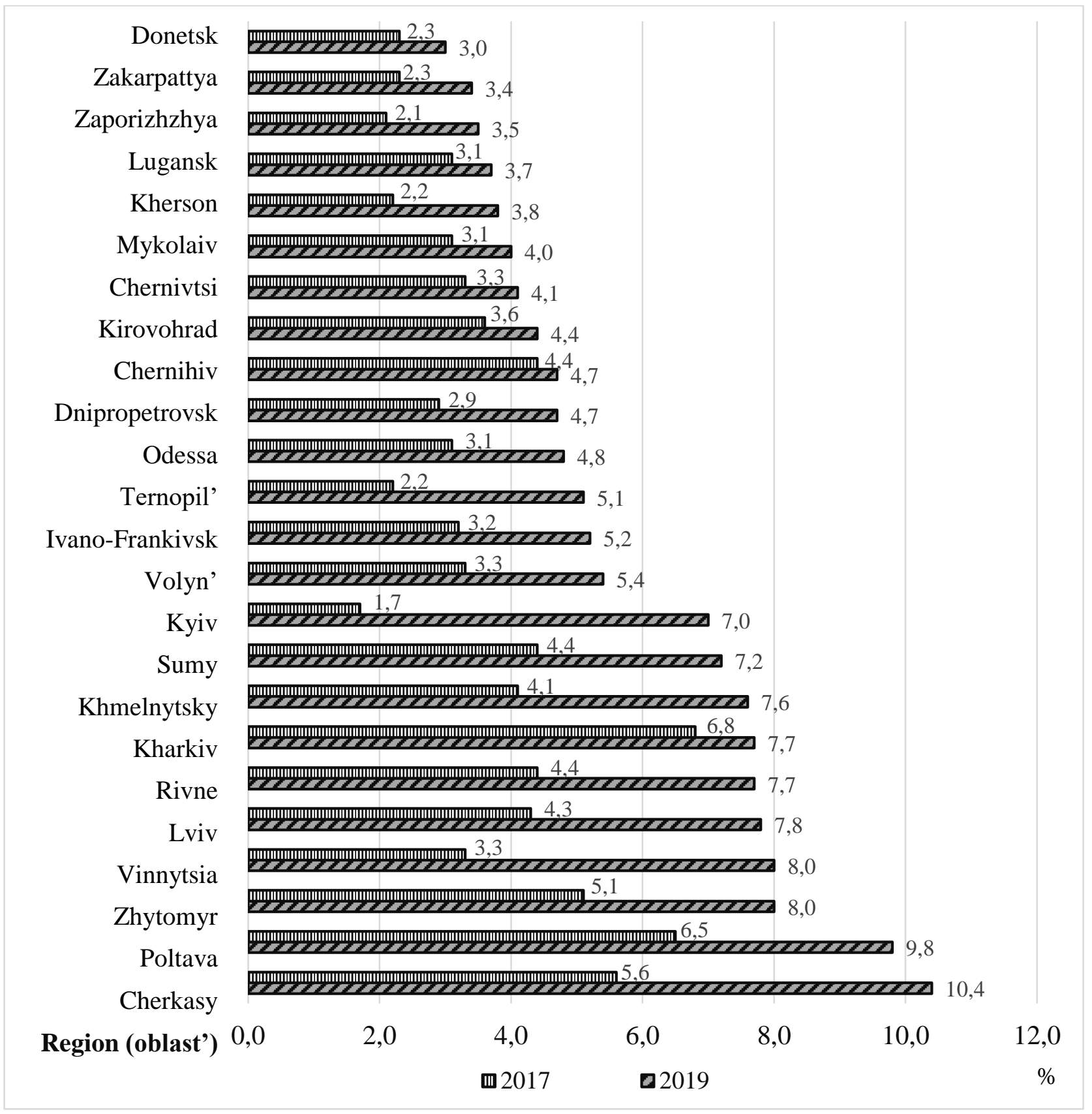

Fig. 1. The percentage of the average annual rental payments for land plots to the value of normative monetary assessment of arable and fallow lands, by regions of Ukraine, $\%$ 
Source: authors' calculations.

In general, the values of the results of the ratio of these indicators as of 01.01.2019 vary in the range from 3.0\% - in Donetsk region to $10.4 \%$ - in Cherkasy. The question is why in areas such as Donetsk, Chernivtsi, Kirovograd, where arable land is one of the most valuable by normative monetary valuation, one of the lowest rates of rent payments for land among the regions of Ukraine is observed? It should also be noted that in Zhytomyr region, with the lowest value of arable land in Ukraine, a sufficiently high percentage of the ratio of rent payments to the normative monetary valuation has been achieved. This situation makes it possible to conclude that the normative monetary valuation is biased for the capitalization of agricultural land.

We believe that one of the options for an objective assessment of land in order to further capitalize it in the absence of a full-fledged land market is precisely the value of the lease rights. Thus, overseas land has a significant share in the land valuation activity by the value of rent. The valuation is carried out by capitalization of the rent $[16 ; 19]$.

The main purpose of letting the land is to earn income on invested capital, that is, land capital. Assuming that the land does not lose its value due to amortization and is rented out on an annuity basis, then the annual income on land capital is determined by the tenant's fee to the owner for the use of the land. The size of this fee is directly proportional to the value of the land capital, and the capitalization rate recognized by the market is the ratio of proportionality. On this basis, the value of land capital (LC) can be calculated as the product of the average annual rent for land and its capitalization period by the formula:

$$
L C=R \times T_{k},
$$

where $R$ is the value of the average annual land lease payment;

$T_{k}$ is the lease capitalization term (in years). 
The question arises of defining the term of the capitalization of the lease as the annual income on land capital. In the old version of the Methodology for normative monetary valuation of agricultural lands and settlements, the capitalization of rental income was at the level of 33 years, which corresponds to a three percent payment for land use. In the current methodology of normative monetary valuation of agricultural land, it is tied to the NBU discount rate. However, the NBU discount rate is a rather unstable indicator (it has varied over the last 5 years in the range of 12.5-30\%), and land, unlike other means of production, is the most stable object of investment and remains a constant in the sphere of production. It is worth noting that in the world economic practice, the period of capitalization of rental income ranges from 20 to 50 years [16-19]. Thus, taking into account the world experience and reference and domestic practices and conditions of agricultural production, we consider that the term of capitalization can be at the level of 33 years.

Using the proposed approach of agricultural land valuation in the absence of a complete land market and given a reasonable capitalization period of 33 years, as well as the value of the average annual rent for land plots, the value of arable and fallow land was estimated in the regions of Ukraine.

Table 3

Calculation of arable and fallow lands for assessment of land capital in the regions of Ukraine as of 01.01. year, UAH / ha

\begin{tabular}{|l|c|c|c|c|c|c|}
\hline \multirow{2}{*}{\multicolumn{1}{|c|}{ Region (oblast') }} & \multicolumn{3}{|c|}{ Value } & \multicolumn{3}{c|}{ Ratio to NGO, \% } \\
\cline { 2 - 7 } & $\mathbf{2 0 1 7}$ & $\mathbf{2 0 1 8}$ & $\mathbf{2 0 1 9}$ & $\mathbf{2 0 1 7}$ & $\mathbf{2 0 1 8}$ & $\mathbf{2 0 1 9}$ \\
\hline Vinnytsia & 35999,7 & 49638,6 & 71474,7 & 108,8 & 183,3 & 264,0 \\
\hline Volyn' & 32653,5 & 35217,6 & 38494,5 & 109,1 & 163,0 & 178,2 \\
\hline Dnipropetrovsk & 31346,7 & 33425,7 & 42104,7 & 96,4 & 123,4 & 155,5 \\
\hline Donetsk & 26086,5 & 28997,1 & 31204,8 & 74,8 & 93,0 & 100,1 \\
\hline Zhytomyr & 34785,3 & 41787,9 & 55674,3 & 169,0 & 197,4 & 263,0 \\
\hline Zakarpattya & 19668,0 & 23723,7 & 30709,8 & 74,6 & 86,2 & 111,6 \\
\hline Zaporizhzhya & 23806,2 & 26225,1 & 28974,0 & 70,4 & 103,8 & 114,7 \\
\hline Ivano-Frankivsk & 30330,3 & 36448,5 & 45048,3 & 106,2 & 139,1 & 172,0 \\
\hline Kyiv & 17602,2 & 50777,1 & 60284,4 & 55,1 & 193,8 & 230,1 \\
\hline Kirovohrad & 38550,6 & 46500,3 & 46939,2 & 120,1 & 144,8 & 146,2 \\
\hline Lugansk & 27551,7 & 28512,0 & 33359,7 & 103,9 & 105,3 & 123,2 \\
\hline
\end{tabular}




\begin{tabular}{|l|c|c|c|c|c|c|}
\hline Lviv & 37365,9 & 48589,2 & 56878,8 & 140,4 & 220,4 & 258,0 \\
\hline Mykolaiv & 27053,4 & 27251,4 & 35501,4 & 102,6 & 100,6 & 131,1 \\
\hline Odessa & 28944,3 & 32175,0 & 49397,7 & 103,0 & 103,2 & 158,5 \\
\hline Poltava & 74025,6 & 84249,0 & 98013,3 & 216,1 & 278,2 & 323,7 \\
\hline Rivne & 45266,1 & 49381,2 & 55743,6 & 144,1 & 224,0 & 252,8 \\
\hline Sumy & 43154,1 & 69306,6 & 63376,5 & 146,6 & 260,2 & 237,9 \\
\hline Ternopil' & 22185,9 & 40986,0 & 48345,0 & 73,9 & 141,8 & 167,3 \\
\hline Kharkiv & 73111,5 & 69663,0 & 82325,1 & 224,9 & 214,0 & 252,9 \\
\hline Kherson & 25172,4 & 27795,9 & 30587,7 & 72,5 & 114,1 & 125,5 \\
\hline Khmelnytsky & 46130,7 & 52866,0 & 74820,9 & 133,7 & 177,2 & 250,7 \\
\hline Cherkasy & 73111,5 & 97739,4 & 116315,1 & 183,6 & 288,1 & 342,8 \\
\hline Chernivtsi & 36672,9 & 43672,2 & 45028,5 & 107,9 & 132,4 & 136,5 \\
\hline Chernihiv & 35590,5 & 39326,1 & 37214,1 & 145,7 & 164,7 & 155,9 \\
\hline Average in Ukraine: & $\mathbf{3 6 0 8 2 , 2}$ & $\mathbf{4 5 1 7 7 , 0}$ & $\mathbf{5 3 2 4 2 , 2}$ & $\mathbf{1 1 6 , 6}$ & $\mathbf{1 6 4 , 2}$ & $\mathbf{1 9 3 , 5}$ \\
\hline
\end{tabular}

Source: calculated according to the analytical data of the State Geocadastre (excluding the Autonomous Republic of Crimea and the temporarily occupied territories in Donetsk and Luhansk regions).

As we can see from the table. 3 the value of arable land by our proposed method is higher than the normative monetary valuation for all three years of analysis. In particular, in 2018, this value exceeded the normative monetary value in Ukraine by an average of $93.5 \%$ or almost doubled.

Conclusions. Thus, in order to attract land to economic circulation, it is advisable to use it as land capital, that is, a source of pricing in the long-term chain of economic reproduction. The key factor in the capitalization of land resources can be considered as an appropriate current market transformation is the value of land capital in agriculture. The primary measure in the formation of land capital in agriculture, under the conditions of institutionally restricted regime of the law of supply and demand, is the capitalization of leased land. The process of transformation of land plots into a special investment instrument - land assets, the main condition for their formation is to reflect them in the balance sheet of the lessee at the cost of capitalized rent payments. This will actually increase the assets of the agricultural producer.

\section{References}

1. Bogdanov, A.V. (2014), Razvitie arendnyh otnoshenij v Rossii na sovremennom jetape [The development of rental relations in Russia at the present 
stage]. Agroprodovol'stvennaja politika Rossii [Agri-food policy of Russia], 1, 1519.

2. Dorosh, J. \& Dorosh, O. (2015), Metodolohichni pidkhody formuvannia rynku orendy zemel' sil's'kohospodars'koho pryznachennia [Methodological approaches to the formation of the agricultural land lease market]. Zemlevporiadnyj visnyk [Land management newsletter], 7, 23-27.

3. Zemel'nyj kodeks Ukrainy: v redaktsii vid 25.10.2001 № 2768-III. Retrieved from https://zakon.rada.gov.ua/laws/show/2768-14.

4. Ibatullin, Sh. I. (2007), Kapitalizatsiia zemel' prymis'kykh zon velykykh mist: teoriia, metodolohiia, praktyka [Capitalization of suburban areas of large cities: theory, methodology, practice], NAU, Kyiv, Ukraine.

5. Ibatullin, Sh.I., Stepenko, O.V., Sakal', O.V. et al. (2012), Mekhanizmy upravlinnia zemel'nymy vidnosynamy $v$ konteksti zabezpechennia staloho rozvytku [Land management mechanisms in the context of sustainable development], IEPSR NANU, Kyiv, Ukraine.

6. Lazarieva, O. V. (2012), Osoblyvosti formuvannia zemel'noho kapitalu [Features of formation of land capital]. Naukovi pratsi Chornomors'koho derzhavnoho universytetu imeni Petra Mohyly. Seriia: Ekonomika [Scientific papers of the Black Sea State University named after Petro Mohyla. Series: Economics], 189(177), 146-148.

7. Martyn, A.H. (2013), Onovlennia metodychnykh zasad normatyvnoi hroshovoi otsinky zemel' sil's'kohospodars'koho pryznachennia [Updating of methodological bases of normative monetary valuation of agricultural lands]. Zemleustrij i kadastr [Land management and cadastre], 3, 30 - 51.

8. Tax Code of Ukraine: The Law of Ukraine: v redaktsii vid 02.12.2010 p. № 2755-VI, available at: http://zakon3.rada.gov.ua/laws/show/2755-17.

9. Cabinet of Ministers of Ukraine (2016), Resolution of the Cabinet of Ministers of Ukraine [On approval of the methodology for regulatory monetary valuation of agricultural land]. Ofitsijnyj visnyk Ukrainy, 93, 131.

10. Cabinet of Ministers of Ukraine (1995), Resolution of the Cabinet of 
Ministers of Ukraine [About the methodology for regulatory monetary valuation of agricultural lands and settlements], ZP Ukrainy, 6, 151.

11. Stupen', R.M. (2018), Rynok zemel' sil's'kohospodars'koho pryznachennia v Ukraini: stan ta perspektyvy rozvytku [Agricultural Land Market in Ukraine: Status and Prospects for Development], DKS-Tsentr, Kyiv, Ukraine.

12. Tretiak, A.M. (2011), Zemel'nyj kapital: teoretyko-metodolohichni osnovy formuvannia ta funktsionuvannia [Land capital: theoretical and methodological foundations of formation and operation], SPOLOM, L'viv, Ukraine.

13. Tretiak, A.M. (2012), Teoretychni osnovy formuvannia zemel'noho kapitalu iak pokhidnoho vid pryrodnoho ta liuds'koho [Theoretical bases for the formation of land capital as derived from natural and human]. Ekolohichni nauky [Environmental sciences], 1, 15-26.

14. Shkuratov, O.I. (2012), Rol' pryrodno-resursnoho kapitalu v protsesi ekolohizatsii ahrarnoho vyrobnytstva [The role of natural resource capital in the process of greening agricultural production]. Innovatsijna ekonomika [Innovative economy], 11, 127-129.

15. Shkuratov, O.I. and Kiurcheva, N.V. (2011), Rozvytok investytsijnoi diial'nosti v ahrarnomu sektori ekonomiky Ukrainy [Development of investment activity in the agricultural sector of the Ukrainian economy], TOV «Kondor», Kyiv, Ukraine.

16. Baker, T., Boehlje, M. and Langemeier, M. (2014), "Farmland: Is it Currently Priced as an Attractive Investment?" American Journal of Agricultural Economics? 96(5), 1321-1333.

17. Capitalizing on Natural Resources: New Dynamics in Financial Markets (2008), The Sustainability Forum Zurich, Zurich.

18. Clark, J.S., Klein, K.K. and Thompson, S.J. (1993), Are subsidies capitalized into land values? Some time series evidence from Saskatchewan. Canadian Journal of Agricultural Economics, 41, 155-168.

19. Stokes, J. and Jansen, J. (2018), The Economics of the 
Capitalization Rate for Farmland. Agricultural Economics, 7, 1-8.

Дорош Й., Шкуратов О., Тарнопольський А.

ЗЕМЕЛЬНИЙ КАПІТАЛ В СІЛЬСЬКОМУ ГОСПОДАРСТВІ: ОСОБЛИВОСТІ ОЦІНКИ ТА ФОРМУВАННЯ

В статье определено, что земельные ресурсы являются не только базисом для размещения производственных сил и основным средством производства в сельском хозяйстве, но и выступают эффективным элементом инвестиционного капитала аграрных предприятий - земельным капиталом. Доказано, что в существующих институциональных условиях земельные ресурсы не создают капитала в аграрном производстве, что требует обоснования механизмов вовлечения их в экономический оборот с целью инвестиционного обеспечения аграрного сектора экономики. Это повышает значимость развития теоретико-методических основ оценки и формирования земельного капитала в сельском хозяйстве Украины.

Установлено, что одним из ключевых факторов капитализации земель сельскохозяйственного назначения является их объективная оченка, которая соответствует нынешним условиям хозяйствования и раскрывает их как источник капитализированных доходов. На основании проведенных исследований взаимосвязей арендных платежей и нормативной оценки земель установлена несопоставимость этих показателей в большинстве регионов Украины. Как результат, доказана необъективность применения нормативной денежной оценки для определения стоимости земельного капитала.

Определено, что одним из путей оценки и формирования земельного капитала в сельском хозяйстве, в условиях институционально ограниченного режима действия закона спроса и предложения, является капитализация арендованных земель. При этом стоимость земельного капитала можно рассчитать как произведение среднегодовой арендной платы за землю и срока его капитализации. Перспективным направлением исследований в 
контексте проведенного анализа является обоснование прочесса зачисления сельскохозяйственных земель на баланс предприятия по стоимости капитализированных арендных платежей.

Ключевые слова: земельный капитал, сельское хозяйство, капитализации, инвестицฺи, нормативная денежная оченка, аренда.

Дорош Й., Шкуратов О., Тарнопольський А. ЗЕМЕЛЬНИЙ КАПІТАЛ В СІЛЬСЬКОМУ ГОСПОДАРСТВІ: ОСОБЛИВОСТІ ОЦІНКИ ТА ФОРМУВАННЯ

У статті визначено, щуо земельні ресурси є не тільки базисом для розміщення виробничих сил та основним засобом виробництва в сільському господарстві, а й виступають ефективним елементом інвестиційного капіталу аграрних підприємств - земельним капіталом. Визначено, щуо в існуючих інституціональних умовах земельні ресурси не створюють капіталу в аграрному виробнищтві, щзо потребує обгрунтування механізмів залучення ӥх в економічний обіг з метою інвестиційного забезпечення аграрного сектора економіки. Це підвищує значущість розвитку теоретикометодичних засад оцінки та формування земельного капіталу в сільському господарстві Украӥни.

Встановлено, щ⿻о одним з ключових чинників капіталізації земель сільськогосподарського призначення $\epsilon$ їх об'єктивна очінка, щуо відповідає нинішнім умовам господарювання та розкриває їх як джерело капіталізованих доходів. На підставі проведених досліджень взаємозв'язків орендних платежів та нормативної оцінки земель виявлена неспівставність цчих показників в більшості регіонів України. Як результат, доведена необ 'єктивність застосування нормативної грошової очінки для визначення вартості земельного капіталу.

Визначено, щзо одним із иляхів оцінки та формування земельного капіталу в сільському господарстві, в умовах інституційно обмеженого режиму дї закону попиту і пропозищї, є капіталізація орендованих земель. 
При изьому вартість земельного капіталу можна розрахувати, як добуток середньорічної орендної плати за землю $i$ терміну його капіталізації. Перспективним напрямом досліджень в контексті проведеного аналізу $\epsilon$ обтрунтування прочесу зарахування сільськогосподарських земель на баланс підприємства за вартістю капіталізованих орендних платежів.

Ключові слова: земельний капітал, сільське господарство, капіталізація, інвестиції, нормативна грочова оцінка, оренда. 